\title{
Descriptive currents in philosophy of religion for Hebrew Bible studies
}

\begin{abstract}
Author:
Jacobus W. Gericke

Affiliation:

${ }^{1}$ Faculty of Humanities, North-West University, Vaal Triangle Campus, South Africa

Correspondence to: Jaco Gericke

email:

21609268@nwu.ac.za

Postal address:

22 Dromedaris, Toon

van den Heever Street,

Sasolburg 1947, South Africa

Dates:

Received: 13 May 2010

Accepted: 30 Sept. 2010

Received: 14 Mar. 2011

How to cite this article:

Gericke, J.W., 2011,

'Descriptive currents in

philosophy of religion for

Hebrew Bible studies'

HTS Teologiese Studies/

Theological Studies 67(3),

Art. \#855, 8 pages. DOI:

$10.4102 /$ hts.v67i3.855
\end{abstract}

C) 2011. The Authors. Licensee: OpenJournals Publishing. This work is licensed under the Creative Commons Attribution License.
This article argued that the utilisation of philosophy of religion in the study of the Hebrew Bible is possible if we look beyond the stereotype of erroneously equating the auxiliary field with natural theology, apologetics or atheological criticism. Fruitful possibilities for interdisciplinary research are available in the form of descriptive varieties of philosophy of religion primarily concerned with understanding and the clarification of meaning rather than with the stereotypical tasks of propositional justification or critical evaluation. Three examples are discussed in the article: analytic traditions (Wittgensteinianism and ordinarylanguage philosophy), phenomenological perspectives involving reduction (bracketing) and comparative philosophy of religion that works in tandem with the history of religion and comparative religion.

\section{Introduction}

In this article, the possibility of utilising philosophy of religion as exegetical tool in biblical scholarship was looked at. Traditionally, the two fields were thought to be incommensurable and crossing disciplinary lines considered a hermeneutical fallacy (Barr 1995:3, 1999:146). However, although many evaluative forms of philosophy of religion are indeed methodologically incompatible with the historical and descriptive biblical concerns of biblical criticism, this is not the case with descriptive varieties; only the hostility to philosophy in 20th century biblical theology has blinded us from fruitful interaction. One of the first scholars to recognise and articulate the new vision against the grain was Knierim (1995), who wrote the following in discussing the possibility of philosophical explication:

Someone may ask whether the reach into this dimension of the questions does not amount to a biblical philosophy or a philosophy of the biblical truth. Indeed! And what would be wrong with that? Would it not, while focusing on the Bible, be in contact with philosophy of religion and with philosophy in principle, as biblical philosophy's contribution to those fields? Would it not, together with these fields, be concerned with the questions of reality, world, facts, meanings, language and truth, including the Bible's own foci and position on these matters in each of the testaments?

(Knierim 1995:410)

Knierim never worked out the details of his program to the extent of linking it up with specific currents within philosophy of religion. In this article, I shall try to flesh out actual possibilities for putting much of Knierim's idea into practice. Given biblical scholarship's descriptive concerns, I have therefore identified three descriptive varieties of philosophy of religion, elements of which, when adopted, adapted and sensibly combined, might offer functional philosophical tools for the Hebrew Bible scholar interested in a descriptive clarification of meaning. These are:

- Analytic traditions of the Wittgensteinian type, concerned with the philosophical clarification of meaning in ordinary language (allowing us to work descriptively with non-philosophical materials).

- Phenomenological approaches interested in reduction (bracketing post-biblical dogmas) that qualifies as descriptive philosophy of religion (allowing us to work historically without the need for justification or critique).

- Comparative philosophy able to deal with conceptual frameworks from the developing world and the complexities of religious pluralism (allowing us to deal with the multiplex nature of the Hebrew Bible and external concepts and categories).

The discussion that follows is bound to be oversimplified and highly selective. Even so, I hope that it will demonstrate the possible usefulness of certain ideas within the aforementioned currents in philosophy of religion. In this way, I intend to show that those who study the Hebrew Bible can now actually 'do' philosophy, rather than simply mining it for concepts or using it as metacommentary. 


\section{Descriptive currents in philosophy of religion \\ Analytic traditions}

If examined, what many Christian analytic philosophers of religion are doing would not be considered of any use for historical purposes. Yet, analytic philosophy of religion is itself part of the broader loose movement of family resemblances called 'analytic philosophy'. As Harris (2002) notes:

\begin{abstract}
Although there are many similarities in methodology, interests, emphases, and results among various philosophers who are commonly regarded as belonging within the analytic tradition, analytic philosophy is not and has never been monolithic. There are also widespread and significant differences among analytic philosophers concerning their methodology, interests, emphases and results. In all, analytic philosophy is a very heterogenous 'movement'. Although there are some common themes, there is also much variety among analytic philosophers in their fundamental philosophical commitments and positions as there has been among idealists or realists or theologians; consequently, it is misleading to talk about 'analytic philosophy' as a single movement in philosophy without recognizing the significant differences among analytic philosophers.
\end{abstract}

(Harris 2002:3)

When the history of analytic philosophy is looked into as such, a number of interesting people and perspectives are found that, given their concern with description, clarification and meaning, might be of use. Especially relevant perspectives in analytic philosophy for biblical scholars interested in descriptive philosophical analysis are those philosophers that sought to reject sweeping philosophical systems in favour of close attention to detail, common sense and ordinary language (see Inson 2005). A classical example here is the earlier Ludwig Wittgenstein (2001a), who wrote in his TractatusLogico-Philosophicus that:

4.112 Philosophy aims at the logical clarification of thoughts. Philosophy is not a body of doctrine but an activity. A philosophical work consists essentially of elucidations. Philosophy does not result in 'philosophical propositions', but rather in the clarification of propositions. Without philosophy thoughts are, as it were, cloudy and indistinct: its task is to make them clear and to give them sharp boundaries.

(Wittgenstein 2001a:51)

The early Wittgenstein thought he had completed the task of philosophy, but in the course of the years to follow his ideas changed to such an extent that he thought he was inventing a new subject. This 'later' Wittgenstein (2001b) then further elaborated on the descriptive task in his Philosophical Investigations, stating that:

123. A philosophical problem has the form, 'I don't know my way about'.

124. Philosophy may in no way interfere with the actual use of language, it can in the end only describe it. For it cannot give it any foundation either.

It leaves everything as it is.

(Wittgenstein 2001b:42)

The clear insistence on taking account of the contexts in life and practice of what we say, have been enormously influential on the philosophy of religion. Yet, our interest is not identical to Wittgenstein's, which sought to make metaphysical problems disappear. Instead, what we take from Wittgenstein is simply the idea of the possibility that philosophy can concern itself with description of what is there in the grammar of the Yahwistic traditions as forms of life.

As Phillips (2009:448) notes, Wittgensteinianism's relation to contemporary analytic philosophy of religion is complex. The use of 'analytic' in this context is not the same as in the label used for the Cambridge and Oxford movements that Wittgenstein influenced. Whereas those movements were antimetaphysical, contemporary analytic philosophy of religion tends to take metaphysical realism for granted too often. Analytic debates about religion in the early days involved both believers and nonbelievers amongst leading philosophers. Wittgenstein's methods are therefore not central in analytic philosophy of religion today, even if it is associated with this current (see Phillips 2009:449) method of philosophy.

One philosopher of religion, who recognised how ordinary language contains all the data necessary to discover the philosophical assumptions of people who may not be philosophical themselves, is Don Cupitt. In a little book called The New Religion of Life in Everyday Speech, Cupitt (1999) discerned philosophy of religion within ordinary language and picked out all the phrases people use that are religiously or philosophically important and interesting. Taking stock of his related work, Cupitt (2005) explained his concern with the philosophical analysis of ordinary language to better understand religious beliefs as follows:

... I decided to take up an idea from Wittgenstein and try to find out what philosophical and religious ideas belong to us all because they are built into the ordinary language that we all share ...Taking up the phrases that are the most provocative and that incorporate the boldest metaphors, and therefore cry out the most insistently for analysis and interpretation, we start to unpack them. It turns out that they often make complex philosophical points in a nutshell. If we then take the next step ... we soon find a complex metaphysics of ordinariness ...

(Cupitt 2005:2)

In this view, the philosophical contents of 'religion' are built into the ordinary language that religious and nonphilosophical people actually use. This is a new and refreshing perspective, quite different from the popular belief that ordinary language philosophy is unsuitable for doing philosophy of religion (contra Mitchell 2007:68). Don Cupitt (2005) also shows that philosophy of religion can work with any religious language, whether itself explicitly philosophical or not:

... at least since Plato, ordinary language's way of thinking have been regarded as low, confused, and simply mistaken ... But the notion that the thought of ordinary people might be intellectually interesting, and might have a logic of its own quite different from the 'academic' or 'platonic' style of thinking traditional in high cultures of the west developed only slowly ... considerations such as these have prepared us very slowly for 
the idea that there really is an interesting philosophy and set of ways of thinking embedded in ordinary language, and that it is about time for us to dig it all out and take a good look at it. When post-Nietzschean philosophers such as Wittgenstein, Dewey and Heidegger came along telling us that we must now learn to think in a post-Platonic, post-metaphysical way, then clearly the time had come for the philosophy that is in ordinariness to emerge. But even at this late date it is proving a difficult birth. Really, very difficult - and nowhere more so than in philosophy of religion.

Cupitt (2005:14-15)

This is something biblical scholars who find no philosophical style arguments in the Hebrew Bible's ordinary language would do well to take cognisance of. One wonders what Israelite religion might look like when constructed from the philosophical assumptions of the ordinary language of characters in the text.

Another interesting and relevant notion comes to us in the writings of D.Z. Phillips, who sought to get beyond Ricoeur's dichotomy in the philosophy of religion that manifests itself in the false dilemma of having to opt for either the hermeneutics of recollection (apologetics) or the hermeneutics of suspicion (atheology) (or both/and). Instead, claims Philips, we also have a third descriptive option in what he calls the 'hermeneutics of contemplation' (see Phillips 2002). On this view, it is perfectly possible to limit one's philosophical concern to clarification and the need to press on to adjudication is the result of our culture's functional obsessions. There is no reason why 'understanding' religion cannot be as an important end in itself than defending or criticising it in the context of another language-game (see Bloemendaal 2006:159).

In these examples of Wittgenstein, Cupitt and Phillips, we see traces of the possibility of descriptive philosophical analysis for biblical scholarship. Note however, that none of the agendas of these philosophers need to be adopted en bloc. Neither do I mean to say that the analytic traditions are where it's at, philosophically speaking. I am well aware of the fact that nowadays analytic philosophy is a cluster of problematic currents in the English-speaking world and that we find ourselves in the context of developing postmodern, post-analytic and post-empiricist approaches. Even so, analytic philosophy of religion is still the most representative current in the discipline within the English-speaking world and conceptual clarity and rigor in argumentation are virtues well worth adopting.

\section{Phenomenological approaches}

Secondly, in being descriptive we also look to phenomenological perspectives. The phenomenology of religion concerns the experiential aspect of religion, describing religious phenomena in terms consistent with the orientation of the worshippers (Wynn 2008:1). It views religion as being made up of different components and studies these components across religious traditions so that an understanding of them can be gained. The scholar need not be a believer and what is perhaps of greatest use is not the entire phenomenological method but the so-called phenomenological reduction or 'ëpoche' in the work of Husserl. Husserl's work indirectly provided the foundation for a descriptive philosophical approach to the intentionality of religious consciousness and a classic application of the theory is that of Van der Leeuw (1963).

Perhaps the most familiar name to biblical scholars is that of Rudolf Otto and his The Idea of The Holy: An Inquiry Into the Non-Rational Factor in The Idea of The Divine and Its Relation to The Rational, which includes a chapter on 'The numinous in the Old Testament' (see Otto 1968). Many biblical scholars who generally have a disdain for philosophy, 'logic' in particular, speak favourably of Otto in one breath and denounce philosophy in the next, without realising that in his reflection on the holy he was using phenomenological tools, thus engaging in descriptive philosophy of religion. Yet, biblical scholars do think that it clarified the texts in some respects and many have been using Otto's philosophical jargon, showing that philosophy of religion was not the enemy, only the use of the distortive currents therein.

A more recent and excellent defence of phenomenology of religion as a descriptive philosophy of religion can be found in Merold Westphal's God, Death and Guilt: An Existential Phenomenology of Religion. Westphal (1987) argues for an alternative to philosophical approaches to religion that limit themselves to evaluation and explanation. Not that these aims are wrong in themselves, but in as much as the question of meaning precedes the question of truth, one must also recognise the legitimacy and even the priority of a purely descriptive approach. Phenomenology of religion in this sense asks us not to speculate anew on actual reality, but to get more acquainted with what is familiar, yet unknown. Descriptive philosophy is still philosophy and the few excursions to the Hebrew Bible by Westphal show that the phenomenological approach is hermeneutically sound despite being philosophical.

In a chapter entitled, Prolegomena to Any Future Philosophy of Religion That Will Be Able to Come Forth as Prophecy, Westphal (1992) argues that a phenomenological approach is actually the most scientific of approaches to the subject:

The phenomenology of religion, however is a descriptive enterprise. It is concerned with truth, but not with the truth of religious assertions; and it brackets questions of transcendence in order to describe the form and content of religion as an observable phenomenon. Phenomenology of religion discusses God, but it does so by describing various forms of belief in God rather than debating the truths of these beliefs. It is systematically uncommitted regarding the latter question. Therefore the fundamental difference between natural (a) theology and phenomenology of religion is not about God but about religion. Rather, one is normative, the other descriptive.

(Westphal 1992:3)

A little bit further on, Westphal (1992:7) goes on to explain why descriptive philosophy of religion has now replaced normative approaches in phenomenological contexts. 
This is the point at which phenomenologists of religion argue that philosophy of religion can be a science, having taken Kant seriously. They have heard him argue that metaphysics cannot be possible as a science in the transcendent sense, giving objective truth about God, freedom and immorality and also heard him explain that metaphysics can be possible as an immanent science describing the structure of human experience. This is the key to their withdrawal from normative to descriptive philosophy of religion.

Westphal realises that no descriptive philosophical analysis is wholly disinterested and that the ëpoché remains an ideal. But for him, that is what makes it interesting, given philosophy's major challenge to understand the nature of the gap between the God of the Philosophers and the God of Abraham, Isaac and Jacob.

Another phenomenological approach to philosophy of religion (combined with a comparative perspective to be discussed in what follows) can be found in the writings of Keith Ward. In his discussion of the concept of God in several religious traditions (including the Hebrew Bible), Ward (1998) writes:

In this book I have adopted, as far as I can, a phenomenological method. That is, I have tried to look at five major religious traditions as sympathetically as I can, using terms acceptable to those traditions themselves. I have tried to bracket my own beliefs, or at least not let them intrude judgmentally upon the tradition I am considering. Where I have criticized, I have sought to let the criticisms arise from within the traditions themselves, so that they rather pose difficulties within a tradition than reasons for rejecting the tradition altogether.

(Ward 1998:vii)

These two elements, bracketing one's own religiousideological assumptions and allowing only for critique from inside the traditions to clarify pluralism when doing descriptive work, are important for consideration in our own attempt to conceive of a philosophical approach to ancient Israelite religion within descriptive and historical biblical studies aimed at clarification. In this, I am not the first to make use of phenomenological reduction. The following is but one example of something similar in the context of the history of Israelite religion by Steinberg (2005):

$\ldots$ in observing the culture of ancient Israel it is first of all necessary to bracket outall (theological) notions of deity that are post-Kantian, or that are derived even indirectly from NeoPlatonism and Neo-Aristotelianism. Ancient Israelite thinking was pre-scholastic and pre-Aquinas and pre-Christian and preJewish. As a consequence, certain distinctions between categories of being and of thought shared by most contemporary scholars, heirs of Western philosophic developments since the thirteenth century C.E., distinctions that fill this chapter, cannot be ascribed to Israelite thought.

(Steinberg 2005:1)

In other words, the problem is not adopting a philosophical perspective as such, for it can descriptive. The problem is doing the job improperly by reading distortive anachronistic philosophical-theological conceptions of Deity into biblical God-talk. We find something related in the Old Testament theology in the writings of Eichrodt, who was accused by Vriezen to the effect that his way of doing things is not a theology at all, but a phenomenology of Israelite religion (see Barr 1999:82). Whether this is true or not (perhaps thought to be such because Eichrodt claimed to work descriptively only from concerns within the tradition) is, however, not presently our concern.

Of course, there is much more to phenomenological approaches (also plural and changing) than phenomenological reduction. However, it is this element of phenomenological analysis that is of most relevance for the development of a descriptive philosophical approach to Israelite religion. Irrespective of its absolute philosophical merits or problems, the basic attitude behind phenomenological reduction might be functional as a corrective tool in combining historical and philosophical analyses of the Hebrew Bible, as it allows us to bracket both the concern with any supposed extra-textual truth and also anachronistic theological (dogmatic) beliefs about what the texts are saying.

With the analytic-phenomenological combination now in place, we still need a third dimension. One that will allow us to do justice to theological pluralism and historical variability on the one hand and the fact of cultural conceptions from the developing world along with marked differences from classical Christian philosophical theology on the other. Accordingly, we come to a third and final ingredient in our methodological make-up, namely comparative philosophy of religion.

\section{Comparative perspectives}

A third major development, stemming from the late 1960s is perhaps the most relevant to biblical scholarship seeking to involve philosophy of religion. Late in the 19th century, anthropologists did some significant research on ancient and religions from the developing world. There developed an interest in the history and plurality of religions, which soon suffered a setback during the first half of the 20th century with the tendency of neo-orthodox theologians to emphasise the discontinuity between revelation and reason in the context of Christian dogmatics. Although this attitude still prevails in many circles today, things began to change after the mid-19th century and the last few decades of the 20th century has seen the birth of a whole new type of philosophy of religion (Long 2003:474).

Over the last few decades, many philosophers of religion have begun to challenge the assumption that one may not discuss issues outside contemporary varieties of monotheism. This trend coincided with the increasing awareness of global issues and postcolonialism, with technological advancements and multicultural societies. The sharp boundaries between philosophy of religion and the history of religion are no longer justifiable (Long 2003:475). Conceptions of what philosophy of religion is or could be has changed dramatically and it is now possible to study any issue in any religion or religious tradition, both present and past and with the aim of understanding different conceptual frames of reference. 
As Long (2003:475) notes, perhaps the most sustained and fruitful attempt to facilitate comparative philosophy as such has come from Philosophy East and West, an international, interdisciplinary academic journal that seeks to promote literacy on traditions from the developing world of philosophy in relation to Anglo-American philosophy. Philosophy defined in terms of cultural traditions broadly integrates the professional discipline with literature, science and social practices. Until recently, the impact of all this on philosophy of religion has been limited in scope. Most philosophy departments remain concerned with contemporary culture of the developed world. Philosophers of eastern or ancient religions therefore seem rare in the philosophy departments and instead operate in the context of religious studies, where there has been an explosion in philosophical approaches to religion. One instance of the proliferation of perspectives and topics is the series of books Toward a Comparative Philosophy of Religions. This is the first collection that includes contributions not only by philosophers proper, but also by philosophically orientated scholars in theology, the history of religions and anthropology (see Long 2003:475).

One comparative philosopher of religion whose work shows the possibility of a philosophical approach to ancient Israelite religion is Ninian Smart. Smart lamented that philosophy of religion as conventionally practiced had ignored the history of religion and comparative religion. He therefore went on to suggest a three-tiered prolegomenon for the philosophy of religion, structured around the comparative analysis of religions, the history of religions and the phenomenology of a range of (religious) experience and action. He has also raised concerns about the parochialism of contemporary 'analytic' philosophy of religion that has led virtually to its marginalisation within philosophy. More controversial is his suggestion that philosophy of religion, along with the history of religions and anthropology, should 'go wild', implying exegetical hermeneutics and intratextual morphology more than redactive dogmatics (Purushottma 2003:340-366).

Smart thinks that it is impossible to define religion in such a way so as to do justice to the idiosyncrasies of individual traditions. Yet, all religions are riddled with propositions that get their meaning in the context in which they are used. No religious idea should be divorced from the larger conceptual background of which they were part. This form of philosophy of religion is thus itself descriptive, historical and actually devoted to pluralist conceptions of deity. As such, it is ideal for studying intra- and interreligious diversity with reference to ancient Israelite religious traditions in their own contexts and reception history for it is not about constructing normative unified systematic theories or with natural theology and apologetics. As Michael Levine (1997) notes in a review on Smart:

In 'The Philosophy of Worldviews, or the Philosophy of Religion Transformed' ... Smart ... calls for an overhaul of the philosophy of religion that would have it abandon its traditional focus on Western (mostly Christian) theism, along with its focus on the problems of natural theology (evil, immortality etc.) as conceived and treated in the context of Western theism. The changes Smart envisions are so radical that he calls for the 'extension' of the philosophy of religion in favour of what he terms the 'philosophy of worldviews.' What, if anything, remains of the philosophy of religion as traditionally conceived is unclear. But as he sees it, this extended philosophy would be 'the upper story of a building which has as its middle floor the comparative and historical analysis of religions and ideologies, and as a ground floor the phenomenology not just of religious experience and action but of the symbolic life of human beings as a whole'.

(Levine 1997:11)

In other words, one of Smart's major arguments was that philosophy of religion should become a philosophical approach to worldview analysis (Smart 2009). What it implies, is that comparative religion, the history of religion and philosophy of religion can now be combined on an interdisciplinary level as a cross-cultural philosophy of religion aimed primarily at awareness and mutual understanding. I do not wish to get drawn into the debate as to the pros and cons of Smart's views in the context of philosophy proper. Instead, I would like to focus on some of the possibilities that Smart's revisionist prolegomenon offer for a philosophical approach to the pluralist theologies within the Hebrew Bible and in comparison to their reception history.

Given that comparative philosophy of religion is motivated by the diversity of religious experiences and symbols in world religions, our own new descriptive philosophical approach to the Hebrew Bible is motivated by cognisance taken of the intra-religious diversity within the multiplex traditions of the Hebrew Bible. It is also motivated by how alien some of the ancient Israelite beliefs are when compared with ideas in modern Jewish and Christian philosophical theology. Thus, because our concern is description, looking to comparative philosophy of religion means that the pluralism in biblical theology, although a problem for any constructive systematic philosophical perspective, is no longer such. Neither is the fact that our descriptive metalanguage comes from a cultural context different from that of the Hebrew Bible. This can be seen from a short overview of the conceptual challenges recognised in comparative philosophy proper (Quinn \& Talioferro 1999; Smart 2008). Dangers recognised by comparative philosophers include the following fallacies according to Littlejohn (2010; see Wong 2009), the recognition of which many biblical scholars will be appreciative of.

Firstly, descriptive chauvinism is a clear and present danger. It is a hermeneutical fallacy involving recreating the other tradition in the image of one's own. This is reading a text from another tradition and assuming that it asks the same questions or constructs responses or answers in a similar manner as that one with which one is most familiar. For example, philosophers who read Confucius as a virtue ethicist on the model of Aristotle must be on constant guard against this kind of chauvinism. Another example is translating the name of the Chinese text Zhongyongas as 'The Doctrine of the Mean', when it does not pursue the same kinds of virtue analysis in practical reason that Aristotle does in his Nicomachean Ethics.

A second obstacle is normative chauvinism. This is the tendency found in many philosophers to believe that their tradition is best and that insofar as the others are different, they are 
inferior or in error. A common form of normative chauvinism is the belief that unless philosophy is done in a certain kind of way (for example, ratiocinative argument), then it cannot properly be considered philosophy. Many philosophy departments in Europe, Britain and America have never at about including courses in comparative philosophy or even area studies philosophies such as those from China, India or Japan, because these traditions are not perceived as doing 'real philosophy'. Some comparative philosophers believe this is analogous to a person listening to Indian music, realising that it sounds very different from the music of the developed world and concluding that it is not 'real music'. What gets overlooked in such cases is that, whilst the whole concept of a 'philosophical work' or 'musical work' often differs according to each tradition, each tradition-dependent example is intellectually robust and meaningful nonetheless.

Thirdly, there is the problem of incommensurability. Here, we find the inability to translate some concepts in one tradition into meaning and reference in another. Something similar happens when philosophical models differ from others in such fundamental ways as to make it impossible for cultural traditions to understand each other. Alternatively, traditions may differ on what counts as evidence and grounds for decidability, thus making it impossible to make a judgment between them. There is no common or objective decision criterion justifying the preference for one set of claims over another, much less one tradition in its entirety over another. The idea is that each tradition infects the other with a way of seeing and the task is to understand how other conceptual schemes are tied to a life that people have found satisfying and meaningful.

Fourth and finally, there is the illusion of perennialism. A mistake often made in comparative philosophy is to overlook historical change. As those who study any religion in depth know very well, all traditions are plural, complex and evolving. They are not 'perennial' in the sense of being monolithic or static. They not only have tensions with other traditions, but contain internal conflict as well. The point at which comparative philosophers step into the stream of another tradition is always important. They must understand not only the reasons for why a particular view is held in another biblical tradition, but also that it is only one view amongst others that are possible within that particular tradition.

Properly speaking, comparative philosophy of religion does not lead toward the creation of a synthesis of philosophical traditions (as in world philosophy). What we have here is not a new theory but a different sort of philosopher. The goal of comparative philosophy is learning a new language, a new way of talking. Comparative philosophers do not so much inhabit both of the standpoints represented by the traditions from which they draw as they come to inhabit an emerging standpoint different from them all and which is thereby creatively a new way of seeing the human condition.

\section{A parallel: Conceptual clarification in philosophical theology}

The task of descriptive philosophy of religion in biblical scholarship can also be compared to the task of clarification in philosophical theology. Whilst natural theology is a stereotypical philosophical concern, some philosophical theologians, however, now consider propositional justification as needing to be preceded by a more descriptive task, clarification. In the words of the positivist dictum, the question of meaning always precedes the question of truth. On this point, an excellent defence and overview of the validity of the clarifying role in philosophical theology, as opposed to it being confined to natural theology, can be found in Scott MacDonald's What is Philosophical Theology? (MacDonald 2009:17-29). He shows the fallacy inherent in the belief that philosophy without evaluation is not 'real' philosophy. As MacDonald (2009) notes, with reference to natural theology and the obsession with normativity:

The sheer weight of this tradition in philosophy since the seventeenth century and the negligence of other models for philosophical theology make it natural to assume philosophical theology is co-extensive with this kind of natural theology. If we give in to this temptation we implicitly agree to two kinds of limitations on philosophical theology, one limiting the kinds of philosophical activity open to the philosophical theologian, the other limiting the range of issues she can legitimately pursue.

(MacDonald 2009:17)

In defence of making room for clarification, MacDonald (2009) continues:

It is not the case that all philosophical activity is concerned primarily with the truth or epistemic justification of a particular theory or set of propositions or beliefs. In order to have a handy way of referring to the sorts of philosophical reflection I want to call attention to here I will borrow a phrase from Aquinas' philosophical theology 'clarification' (manifestatio). A great deal of philosophical activity is concerned not with justifying but with clarifying propositions or theories.

(MacDonald 2009:23)

In other words, there is room for description in philosophy and it is just as much part of 'doing' philosophy as the critical evaluation of truth claims or the proposal of ideas about what is absolutely the case. Biblical scholars who have not been able to imagine a philosophical approach to the Hebrew Bible in the context of historical work might have overlooked this descriptive option. Moreover, one has to understand just how important the descriptive task actually is, as MacDonald (2009) further explains by way of an analogy (I abbreviate):

I propose to explain what clarification is simply by describing a case in which an ordinary philosopher engages in what I take to be the clarification of a philosophical theory. Imagine a philosopher who works in ethics and is interested in moral realism ... she does not think that realism is true (perhaps she doesn't think it is false either), but finds it intriguing and worth investigating ... Her philosophical agenda includes various kinds of projects, three of which are worth specific mention. First, she gives some attention to analyzing concepts central to moral realism ... Second, she is interested in the internal coherence or consequences of moral realism ... Third, she also 
takes an interest in moral realism's external relations: how does it square with a theistic view of the world ... etc.

(MacDonald 2009:23-24)

Thus, lest there be any suggestion that what I am proposing is not philosophy but only linguistics (lexicography) or anthropology (social-scientific worldview description), I refer the objector to MacDonald's own arguments, showing clarification as a philosophical activity independent of epistemic justification and as fully entitled to the concept of philosophical inquiry as the latter. In this manner, clarification in philosophical theology shows how a descriptive philosophical approach to the Hebrew Bible might operate in historical biblical scholarship, for it both allows us to work with concepts particular to ancient Yahwism and warrants limiting the inquiry to a concern with meaning, rather than truth.

But how does the utilisation of descriptive philosophical analysis in biblical interpretation differ from that in philosophy proper? Well, whilst philosophy of religion working in the contemporary Christian tradition is indeed a normative enterprise reflecting on the truth of religious beliefs, I conceive of the task of a philosophical approach to ancient Israelite religion in the context of biblical studies as involving something a little different. We are biblical scholars, utilising philosophy of religion to understand the Hebrew Bible historically, not philosophers of religion seeking to have the Hebrew Bible contribute to contemporary philosophical debates or hoping to prove its truth-claims wrong. Here lie the fundamental differences between the two contexts involved in the interdisciplinary research and they can be summed up as follows:

From this it should be readily apparent that a descriptive philosophical approach to Israelite religion has a parallel in all descriptive assessments within philosophical subdisciplines. One example is descriptive philosophy of science, which attempts to describe in philosophical terms what science actually does and assumes about the world, as opposed to what science should do or how reality really is. Another instance is the philosophy of art, which seeks to understand the aesthetic phenomenon rather than only trying to defend or criticise art.

TABLE 1: Philosophy of religion.

\begin{tabular}{ll}
\hline Philosophy of religion proper & Philosophy of Israelite religion \\
\hline Christianity or Judaism & Ancient Israelite Yahwism(s) \\
Philosophical concepts & Folk-philosophical assumptions \\
Mainly evaluative & Mainly descriptive \\
Ultimately synthetic & Ultimately analytic \\
Concepts from systematic theology & Concepts from biblical theology \\
Apologetic or atheological & Historical or phenomenological \\
Mainly justification or critique & Only clarification \\
Philosophy/theology & Biblical studies \\
\hline
\end{tabular}

\section{Differences from Thiselton's 'philosophical description'}

The concept of 'philosophical description' was introduced by Anthony Thiselton (1980) in his The Two Horizons: New Testament Hermeneutics and Philosophical Description with Special Reference to Heidegger, Bultmann, Gadamer and Wittgenstein. In this book, Thiselton famously suggested the involvement of linguistic and hermeneutic philosophy for the understanding of the New Testament (1980:3). The discussion begins with the question why interpreters of the New Testament should concern themselves with philosophy and the author spends a certain amount of time arguing for the need to take philosophy seriously in New Testament studies. The first chapter begins: 'Why philosophical description?' After dealing with two objections (concerning fashion and distortion), Thiselton spells out why he thinks philosophical description is useful:

- New Testament scholars use philosophical categories in their work. Thus, any kind of dialogue or critique of such scholars will involve philosophical considerations, if that dialogue is to be taken seriously.

- Philosophy is helpful in describing (the nature of) and appraising the hermeneutical process, as Gadamer has articulated the hermeneutical process as the fusion of two horizons.

- Philosophical hermeneutics bears on a host of issues directly relevant to biblical interpretation, as interpretation inevitably carries with it philosophical issues, as Paul Ricoeur has shown.

A powerful example of the way in which philosophy shapes biblical interpretation is philosophy of language, another philosophical discipline that Thiselton involves. As Bartholomew (1996) writes:

Thiselton has rightly alerted us to the important relationship between philosophy and biblical interpretation, as this is focused in hermeneutics. In all theoretical work epistemological, ontological and anthropological presuppositions provide, as it were, the scaffolding for our theory construction. Such scaffolding is not neutral, and it can only help if we are conscious of the philosophical presuppositions and theories informing and shaping our scholarship. Prior to Wellhausen it was not unusual for an Old Testament scholar to devote a large portion of a published work to explaining and defending his understanding of religion, before going on to apply this to the Old Testament. Wellhausen retained many of the results of such research, but decontextualised his results; he hid the scaffolding, as it were!

(Bartholomew 1996:131)

The postmodern turn has, of course, gone a long way towards exposing hidden scaffolding, which I welcome, but the myth of neutrality in Hebrew Bible scholarship remains widespread. Accordingly, although Thiselton's two major texts on biblical hermeneutics have been widely reviewed, there has been surprisingly little thorough interaction with his work. Bartholomew (1996) again:

And would this affect our handling of the OT? This is not to suggest that OT scholars should become philosophers and theologians. It is to suggest that OT scholarship requires solid philosophical (and theological) input if it is not to work with 
hidden philosophies shaping it. Thus, I suggest, we desperately need scholars like Thiselton who will do the hard philosophical work, and biblical scholars need regular dialogue with such people72. Especially in the USA in recent years there has been a renaissance of Christian philosophy under the leadership of scholars like Alvin Plantinga and Nicholas Wolterstorff. The growing corpus of work that this 'movement' is yielding, and the work of scholars like Thiselton, provide a ready starting point for such dialogue.

(Bartholomew 1996:131)

I would like to disagree with the choice of the philosophers here. We can do better than Reform Epistemology's cryptofundamentalism, even if pluralism is the name of the game and everyone should have their say. But how does the agenda of this study differ from Thiselton's?

Firstly, Thiselton is not much interested in philosophy of religion as such and his focus is almost wholly on hermeneutics. I suppose that, given the hermeneutical current in philosophy of religion itself, one can make a case for overlap, but Thiselton himself does not do so in his book. Moreover, given the focus on hermeneutics, the primary concern of Thiselton lies with a philosophical description of understanding the exegetical context and not only with a philosophical description of the worlds in the text. Also, with regard to the latter, the frame of reference remains hermeneutics. Finally, Thiselton's concern is limited to the New Testament, where philosophy is less of a problem, given the partly Hellenistic historical-cultural context. In these ways then, Thiselton's contribution differs from my own.

\section{Conclusion}

In this article, the availability of descriptive varieties of philosophy of religion that may be of use to biblical scholars interested in the clarification of meaning, as opposed to the critical evaluation of truth claims was looked at. The antiphilosophical sentiment in biblical scholarship has prevented the fruitful utilisation of these perspectives. What is perhaps most interesting of all, is the fact that all of the traditional objections to the involvement of philosophy turned out to be irrelevant. Whilst such objections have a point as long as philosophy of religion is erroneously equated with natural theology, apologetics or atheological critique, they do not apply to descriptive approaches in philosophical analysis. The aim of these approaches is neither to read philosophy into the text nor to construct a systematic philosophy of religion from it and is concerned only with the clarification of meaning. Therefore, they provide access to metaphysical, epistemological, moral and other folk-philosophical assumptions in the discourse other approaches cannot access. If this is true, it means that without philosophical elucidation, the most fundamental aspects of biblical worldviews will remain a mystery and descriptive philosophy of religion is needed precisely in order to prevent anachronistic philosophical-theological distortions of biblical beliefs. Seen in this way, a descriptive philosophical reading is not something over and against a literary-historical approach but a necessary supplement to it.

\section{References}

Barr, J., 1994, Biblical Faith and Natural Theology, Oxford, Oxford University Press. doi:10.1093/0198263767.001.0001

Barr, J., 1999, The Concept of Biblical Theology, Fortress Press, Philadelphia.

Bartholomew, C.G., 1996, 'Three Horizons: Hermeneutics from the Other End - An Evaluation of Anthony Thiselton's Hermeneutic Proposals', European Journal of Theology 5(2), 131.

Bloemendaal, P.F., 2006, Grammars of Faith: A Critical Evaluation of D.Z, Phillip's Philosophy of Religion, Studies in Philosophical Theology, Peeters Press, Leuven/ Paris.

Cupitt, D., 1999, The New Religion of Life in Everyday Speech, London, SCM Press.

Cupitt, D., 2005, The Way to Happiness, Polebridge, London.

Glock, H.J., 2008, What is Analytic Philosophy?, Cambridge University Press, Cambridge.

Harris H., \& Christopher I., 2005, Faith and Philosophical Analysis: The Impact of Analytical Philosophy on Philosophy of Religion, Ashgate Publishing, London.

Harris, J.F., 2002, Analytic Philosophy of Religion, Kluwer Academic Publishers, London.

Jones, R.B., 1997, 'Varieties of Philosophical Analysis', History of Philosophy Overview, viewed 15 February 2010, from http://www.rbjones.com/rbjpub/philos/history/ his003.htm

Knierim, R.P., 1995, The Task of Old Testament Theology: Method, Substance, Cases, William B Eerdmans, Grand Rapids.

Levine, M.P., 1997, 'Ninian Smart on the Philosophy of Worldviews', Sopbia 36(1), 11. doi: 10.1007/BF02786040

Littlejohn, R., 2010, 'Comparative Philosophy', The Internet Encyclopedia of Philosophy, viewed 10 January 2010, from http://www.iep.utm.edu/

Long, E.T., 2003, Twentieth Century Western Philosophy of Religion, Kluwer Academic Publishers, London.

MacDonald, S., 2009, 'What is Philosophical Theology?', in K. Timpe (ed.), Arguing about Religion, pp. 17-29, Routledge, New York

Martinich. A. \& Sosa, D., 2001, A Companion to Analytic Philosophy, vol. 20, Blackwell Companions to Philosophy, Wiley-Blackwell, New York.

Mitchell, C.V., 2007, Charts of Philosophy and Philosophers, Zondervan, Grand Rapids.

Otto, R., 1968, The Idea of the Holy, Galaxy Books, vol. 14, Oxford University Press, Oxford.

Phillips D.Z., 2001, Religion and the Hermeneutics of Contemplation, Cambridge University Press, Cambridge. doi: 10.1017/CBO9780511612718

Phillips, D.Z., 2005, 'Wittgensteinianism: Logic, Reality and God', in W. Wainright (ed.), Oxford Handbook of Philosophy of Religion, pp. 448-455, New York, Oxford University Press.

Purushottma, B., 2003, "What is The "Sub-Altern" of the Comparative Philosophy of Religion?', Philosophy East and West 53(3), 340-366. doi: 10.1353/pew.2003.0019

Quinn, P. \& Taliaferro, C., 1999, A Companion to Philosophy of Religion, London, WileyBlackwell. doi: 10.1111/b.9780631213284.1999.x

Smart, N., 1995, 'The Philosophy of Worldviews, or the. Philosophy of Religion Transformed', in T. Dean (ed.), Religious Pluralism and Truth: Essays on CrossCultural Philosophy of Religion, pp. 17-31, State University of New York Press, Albany.

Smart, N., 2008, World Philosophies, ed. O. Leaman, Routledge, New York.

Smart, N. \& Shepherd, J.T., 2009, Ninian Smart on World Religions: Selected Works, Ashgate Publishing Ltd., Oxford.

Steinberg, D., 2005, Israelite Religion to Judaism: the Evolution of the Religion of Israel, viewed 19 July 2009, from http://www.adath-shalom.ca/israelite_religion. htm.

Thiselton, A., 1980, The Two Horizons: New Testament Hermeneutics and Philosophica Description with Special Reference to Heidegger, Bultmann, Gadamer and Wittgenstein, William B Eerdmans, Grand Rapids.

Van der Leeuw, G., 1963, Religion in Essence and Manifestation: A Study in Phenomenology, transl. J.E. Turner, 2 vols., Harper \& Row, New York.

Ward, K., 1998, Concepts of God, Oneworld Publications, Oxford.

Westphal, M., 1987, God, Guilt and Death: An Existential Phenomenology of Religion, Indiana University Press, Bloomington.

Westphal, M., 1992, Kierkegaard's Critique of Reason and Society, Penn State Press, Bloomington.

Westphal, M., 1998, 'Phenomenology of Religion', in Edward Craig (ed.), Routledge Encyclopedia of Philosophy, vol. 1, pp. 352-355, Taylor \& Francis, London.

Wittgenstein, L., 2001a, TractatusLogico-Philosophicus, transl. G.E.M. Anscombe, Wiley-Blackwell, New York.

Wittgenstein, L., 2001b, Philosophical Investigations, transl. G.E.M. Anscombe, WileyBlackwell, New York.

Wong, D., 2009, 'Comparative Philosophy: Chinese and Western', Stanford Encyclopedia of Philosophy (Winter 2009 Edition), viewed 16 May 2009, from http://plato.stanford.edu/archives/win2009/entries/comparphil-chiwes/

Wynn, M., 2008, 'Phenomenology of Religion', Stanford Encyclopedia of Philosophy (Winter 2008 Edition), viewed 12 March 2009, from http://plato.stanford.edu/ archives/win2008/entries/phenomenology-religion/ 